\title{
Protonpumpehemmere og magekreft
}

\author{
Langtidsbivirkninger av medisiner kan overses i randomiserte, kontrollerte legemiddelutprøvninger fordi \\ oppfølgingstiden er for kort. Vi har lenge visst at protonpumpehemmere gir magekreft hos gnagere, og det \\ er ingen åpenbar biologisk grunn til at dette skulle være annerledes hos menneske.
}

Når protonpumpen hemmes, synker $\mathrm{H}+-$ konsentrasjonen i ventrikkelen. Dette fører til gastrinfrigjøring. Gastrin er den viktigste regulatoren av surhetsgraden i magesekken. Den stimulerer syreproduksjonen indirekte ved å stimulere histaminfrigjøring fra ECLcellen (enterochromaffin-like cells) (1). Gastrin virker også inn på ECL-cellen ved å stimulere proliferasjon (2). Dette er det biologiske grunnlaget for at langvarig hypergastrinemi også kan gi utvikling av svulster utgående fra gastrinets målcelle, ECL-cellen.

Midt i 1980-årene ble det rapportert at protonpumpehemmeren omeprazol ga svulster i ventrikkelen hos rotte (3). Alle kliniske forsøk med denne meget effektive syrehemmeren ble dermed stoppet. Svulstene var lokalisert til den syreproduserende slimhinnen. Imidlertid kunne Nilo Havu i legemiddelfirmaet Astra vise at disse svulstene ikke var adenokarsinomer, som utgjør storparten av ventrikkelkrefttypene hos menneske, men nevroendokrine og utgående fra ECL-cellen (3). Mekanismen ble forklart å være hypergastrinemi som følge av syrehemningen (3). Det ble fra forskjellig hold hevdet at rotten var spesiell og at ECL-cellen ikke spilte noen rolle i svulstutvikling hos menneske. Hypergastrinemi alene ble sagt ikke å være tilstrekkelig til å gi svulstutvikling hos menneske - selv om det var vist hos rotte. Ved ECL-karsinoider ved atrofisk gastritt (4) ble det lagt vekt på gastritten som en faktor i tillegg til hyper-

\section{«Biologisk forståelse er blitt erstattet med blind tiltro til evidens-}

basert medisin»

gastrinemien. Ved ECL-karsinoider hos pasienter med gastrinom sekundært til genfeil som disponerer for nevroendokrine svulster (MEN1) (5), ble genfeilen vektlagt.

\section{Godkjent til tross for kreft}

Protonpumpehemmere ble godkjent for klinisk bruk. Å godkjenne et preparat som hadde gitt malign svulst i målorganet hos forsøksdyr var brudd på tabu, og initialt ble midlene godkjent på meget streng indikasjon. I løpet av årene som har gått, er dette blitt løsnet på, og protonpumpehemmere

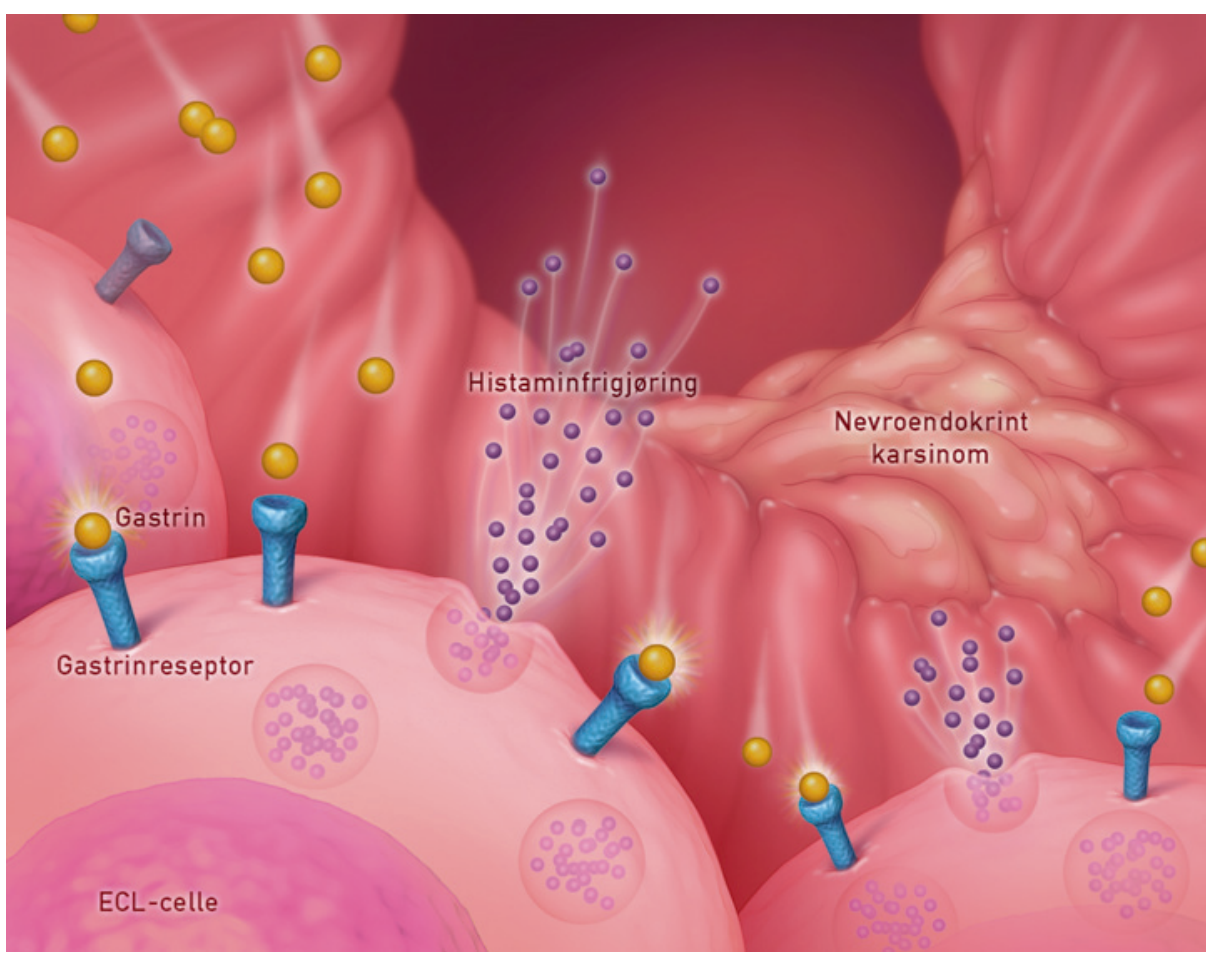

Når H+faller, frigjøres gastrin som stimulerer ECL-cellen til histaminfrigjøring. Gastrin stimulerer også ECL-cellen til proliferasjon. Dette kan føre til hyperplasi og utvikling av kreft, vanligst nevroendokrint karsinom. Illustrasjon: Scott Leighton/Medicus Media

kan nå forskrives mot en rekke sykdommer, inkludert dyspepsi. De er også godkjent for bruk hos ungdom og barn ned i spedbarnsalder.

I starten var det usikkerhet om klassifiseringen av svulstene hos rottene som ble eksponert for protonpumpehemmere. Svulster man først trodde var adenokarsinomer, hadde vist seg å være nevroendokrine svulster. Med bakgrunn i dette begynte vår forskningsgruppe å interessere seg for klassifiseringen av ventrikkelkreft hos menneske. Kunne det være slik at det også her var en feilklassifisering slik at svulster klassifisert som adenokarsinomer i realiteten var nevroendokrine karsinomer utgående fra ECLcellen?

\section{Hypergastrinemi gir kreft}

I løpet en periode på mer enn 20 år har vi kunnet vise at en betydelig del av ventrikkelcancerne hos menneske er nevroendokrine karsinomer $(6,7)$, og vi har derfor hevdet at hypergastrinemi sekundært til medikamentell syrehemning på sikt måtte gi økt risiko for magekreft (8). Det er nå publisert en artikkel som elegant viser at hypergastrinemi alene kan gi ventrikkelkreft også hos menneske (9). Artikkelen omhandler ti søsken, hvorav fire er homozygote for mutasjon i et av genene som koder for protonpumpen. Disse fire har dermed vært uten magesyre og følgelig hypergastrinemiske fra fødselen av. Alle fire utviklet ventrikkelsvulster i en alder rundt 30 år. Tre av svulstene ble klassifisert som ECL-cellekarsinoider, den fjerde som adenokarsinom. Sistnevnte svulst var somatostatin- 2-reseptorpositiv og derfor sannsynligvis et nevroendokrint karsinom. Dette viser entydig at menneske, slik som gnagere, utvikler ECL-cellesvulster av variabel malignitetsgrad sekundært til hypergastrinemi alene.

\section{Blind tiltro til evidensbasert medisin}

Når vi tidligere har hevdet at det kunne være slik, er vi blitt neglisjert eller motarbeidet. Det kan sikkert være mange årsaker til dette, men jeg frykter at en viktig årsak er at biologisk forståelse er blitt erstattet med blind tiltro til evidensbasert medisin. Evidensbasert medisin som eneste kilde til kunnskap har også tidligere fått kritisk omtale i Tidsskriftet (10). Dersom man baserer sin kliniske virksomhet kun på dette vil det gå årtier før man oppdager langtidsbivirkninger. Langtidseffekter vil derimot ofte kunne påvises i dyremodeller. Man bør huske på at rotte 
og menneske er mer enn $90 \%$ genetisk identiske. I dag må man kunne vise at det man finner i forsøksdyr også gjelder hos menneske. Det burde være motsatt: Dersom man finner bivirkninger hos forsøksdyr, bør man bli pålagt å vise at dette $i k k e$ gjelder hos menneske.

En annen årsak til motstanden vi har møtt, kan være økonomi. Jeg vil i den sammenheng nevne en uttalelse fra han som lagde det første bøyelige skopet, norgesvennen Basil Hirschowitz: "You are fighting a product sold for 10 billion dollars a year, you have no chance». Jeg svarte: «In the long run biology will always beat economy».

Helge L. Waldum

helge.waldum@ntnu.no

Helge L. Waldum (f. 1946) er dr.med. og spesialist $\mathrm{i}$ indremedisin og i fordøyelsessykdommer. Han er docteur d'État fra Paris, ridder av 1. klasse av St. Olavs Orden og editor-in-chief i Scandinavian Journal of Gastroenterology. Han er professor ved Norges teknisk-naturvitenskapelige universitet og overlege ved Gastromedisinsk avdeling, St. Olavs hospital.

Forfatter har fylt ut ICMJE-skjemaet og oppgir ingen interessekonflikter.

\section{Litteratur}

1. Waldum HL, Sandvik AK, Brenna E et al. Gastrinhistamine sequence in the regulation of gastric acid secretion. Gut 1991; 32: 698-701.

2. Brenna $E$, Waldum HL. Trophic effect of gastrin on the enterochromaffin like cells of the rat stomach: establishment of a dose response relationship. Gut 1992; 33: 1303-6.

3. Havu N. Enterochromaffin-like cell carcinoids of gastric mucosa in rats after life-long inhibition of gastric secretion. Digestion 1986; 35 (suppl 1): 42-55.

4. Borch K, Renvall H, Liedberg G. Gastric endocrine cell hyperplasia and carcinoid tumors in pernicious anemia. Gastroenterology 1985; 88: 638-48.

5. Solcia E, Capella C, Fiocca R et al. Gastric argyrophil carcinoidosis in patients with Zollinger-Ellison syndrome due to type 1 multiple endocrine neoplasia. A newly recognized association. Am J Surg Pathol 1990; 14: 503-13.

6. Waldum HL, Haugen OA, Isaksen $\mathrm{C}$ et al. Are diffuse gastric carcinomas neuroendocrine tumours (ECL-omas)? Eur J Gastroenterol Hepatol 1991; 3: $245-9$.

7. Waldum HL, Aase S, Kvetnoi I et al. Neuroendocrine differentiation in human gastric carcinoma. Cancer 1998; 83: 435-44

8. Waldum HL, Brenna E, Sandvik AK. Long-term safety of proton pump inhibitors: risks of gastric neoplasia and infections. Expert Opin Drug Saf 2002; $1: 29-38$

9. Calvete O, Reyes J, Zuñiga $S$ et al. Exome sequencing identifies ATP4A gene as responsible of an atypical familial type I gastric neuroendocrine tumour. Hum Mol Genet 2015; 24: 2914-22.

10. Wyller TB. Evidensbasert medisin eller vulgærcochranisme? Tidsskr Nor Legeforen 2011; 131 $1181-2$.

Mottatt 30.9. 2015og godkjent 18.11. 2015. Redaktør: Martine Rostadmo. 